\title{
Use and Application of Photochemical Modeling to Predict the Formation of Tropospheric Ozone
}

\author{
Guarieiro, L. L. N.; Amparo, K. K. S.; Figueirêdo, I. S.; de Andrade, J. B.
}

Rev. Virtual Quim., 2017, 9 (5), 2082-2099. Data de publicação na Web: 24 de outubro de 2017

http://rvq.sbq.org.br

\section{Uso e Aplicação de Modelagem Fotoquímica para Previsão da Formação de Ozônio Troposférico}

\begin{abstract}
High concentrations of tropospheric ozone $\left(\mathrm{O}_{3}\right)$ are considered to be toxic to human beings and may lead to significant oxidative processes in various types of materials. Nitrogen oxides and volatile organic compound emissions are the main precursors of tropospheric $\mathrm{O}_{3}$ formation. Experimental studies have been performed to evaluate the potential for the formation of $\mathrm{O}_{3}$. However, these studies are limited by their inability to simulate natural environmental conditions that contribute significantly to the formation of $\mathrm{O}_{3}$. Computational mathematical models have become an important tool in predicting the formation of $\mathrm{O}_{3}$ because it is possible to simulate specific scenarios of the emissions of environmental pollutants with defined meteorological conditions. A critical analysis was presented of the photochemical models that have been applied to predict the formation of tropospheric $\mathrm{O}_{3}$ and their importance in the evaluation of this pollutant.
\end{abstract}

Keywords: Air quality models; tropospheric $\mathrm{O}_{3}$ formation; mathematical models.

\section{Resumo}

$\mathrm{O}$ ozônio $\left(\mathrm{O}_{3}\right)$ troposférico em alta concentração é um composto tóxico para os seres vivos e pode levar vários tipos de materiais à processos oxidativos significativos. A formação do $\mathrm{O}_{3}$ troposférico tem como principais precursores as emissões de óxidos de nitrogênio e compostos orgânicos voláteis. Estudos experimentais são desenvolvidos para avaliar o potencial de formação do $\mathrm{O}_{3}$. Contudo, tais estudos se tornam restritivos devido à impossibilidade de simulação de condições ambientais naturais que contribuem significativamente com a formação do $\mathrm{O}_{3}$. Neste sentido, modelos matemáticos computacionais se tornam uma ferramenta importante na previsão da formação de $\mathrm{O}_{3}$, uma vez que é possível simular cenários específicos da emissão de poluentes ambientais com condições meteorológicas definidas. Neste contexto, foi realizada uma analise crítica dos modelos fotoquímicos que vem sendo utilizado na avaliação da formação de $\mathrm{O}_{3}$ troposférico e sua importância $\mathrm{n}$ a avaliação da formação deste poluente.

Palavras-chave: Modelos de qualidade do ar; formação de ozônio troposférico; modelos matemáticos.

\footnotetext{
* Centro Universitário SENAI CIMATEC, CEP 41650-010, Salvador-BA, Brazil.

Mlilianguarieiro@gmail.com

DOI: $10.21577 / 1984-6835.20170124$
}

Rev. Virtual Quim. |Vol 9| |No. 5| |2082-2099| 


\title{
Use and Application of Photochemical Modeling to Predict the Formation of Tropospheric Ozone
}

\author{
Lílian L. N. Guarieiro, ${ }^{a, b, *}$ Keize K. S. Amparo, ${ }^{b}$ Ilan S. Figueirêdo, ${ }^{b}$ Jailson \\ B. de Andrade ${ }^{b, c}$ \\ ${ }^{a}$ Centro Universitário SENAI CIMATEC, CEP 41650-010, Salvador-BA, Brazil. \\ ${ }^{b}$ Instituto Nacional de Ciência e Tecnologia em Energia e Ambiente, CEP 40170-290 Salvador- \\ BA, Brazil. \\ c Universidade Federal da Bahia, Instituto de Química, CEP 40170-290 Salvador-BA, Brazil. \\ *liliaguarieiro@gmail.com
}

Recebido em 24 de outubro de 2017. Aceito para publicação em 24 de outubro de 2017

\section{Introduction}

2. Atmosphere Characterization

\section{Atmospheric Pollution}

\section{Photochemical modeling to predict the formation of tropospheric ozone}

4.1. Path Model - Box Models

4.2. Chemical Mechanism

\section{Final Considerations}

\section{Introduction}

The increases in population have led to the consumption of many natural resources, which has resulted in increasing environmental degradation. The burning of fossil fuels by stationary sources (e.g., industries) and mobile sources (e.g., vehicle engines) is considered to be the main cause of air pollution and is a human health hazard. Air pollutants are classified as primary or secondary pollutants. Primary pollutants are emitted into the atmosphere, such as gases from vehicle engines (e.g., carbon monoxide, soot, nitrogen oxides $\left(\mathrm{NO}_{\mathrm{x}}\right)$, sulfur oxides
$\left(\mathrm{SO}_{\mathrm{x}}\right)$, hydrocarbons, aldehydes). Secondary pollutants are compounds resulting from chemical reactions between primary pollutants with substances present in the lower atmosphere and fractions of solar radiation. A typical example of a secondary pollutant is tropospheric ozone $\left(\mathrm{O}_{3}\right)$, which is generated from the decomposition of NOx by ultraviolet radiation from the sun (decomposition of $\mathrm{NO}_{2}$ occurs at wavelength $<430 \mathrm{~nm})^{1,2}$

Although nature mitigates some of the pollution generated in the atmosphere through rainfall, wind dispersion and chemical transformations, it is not sufficient to neutralize the amount of pollution 
generated. Several measures can be taken to control the emissions of these harmful substances. The use of biofuels (ethanol and biodiesel) has emerged as a possibility to replace fossil fuels because they are a source of renewable energy that is produced from organic matter. ${ }^{3}$

There has been a great deal of discussion in the literature about the contribution of biofuels to the formation of secondary pollutants, such as $\mathrm{O}_{3}$, formaldehyde, acetaldehyde and acrolein. With the exception of $\mathrm{O}_{3}$, all these pollutants can be emitted directly from mobile or stationary sources, being considered also primary pollutants. These pollutants highlighted above also deserve attention because they are considered carcinogenic. ${ }^{4,5}$ The chemistry converting volatile organic compounds (VOC) and $\mathrm{NO}_{\mathrm{X}}$ to $\mathrm{O}_{3}$ is very complex. The essential role played by VOC is the oxidation of NO, emitted by combustion processes, to $\mathrm{NO}_{2}$, the precursor of $\mathrm{O}_{3}{ }^{6}{ }^{6}$ In addition, the tropospheric $\mathrm{O}_{3}$ is a toxic compound that can cause eye irritation and respiratory problems. $^{7}$

Due to the short-term (e.g., nose, throat and eye irritation) and long-term (e.g., pulmonary and cardiovascular problems, increased chance of developing cancer) effects of air pollution, it is important that these pollutants be monitored, disclosed and predicted to generate knowledge and awareness in the population as well as to create new control strategies for their mitigation. $^{8}$

The formation of secondary pollutants can be predicted through experimental testing and/or computer models, its choice dependent on the context to be studied. The experimental prediction of the formation of secondary pollutants using reaction chambers is often unable to determine actual weather conditions or a profile of the initial primary pollutants that contribute to the formation of secondary pollutants. Chamber studies have also provided the basis for the validation of computer kinetic models. Finally, they have provided important kinetic and mechanistic information on some of the individual reactions occurring during photochemical smog formation. ${ }^{9}$ Studies of the formation of secondary pollutants use photochemical modeling due to the kinetic complexity of the chemical reactions in the atmosphere, which occur at high speeds and depend on several weather factors, concentrations of other pollutants, transport, photolysis rate, height and stability in the Planetary Boundary Layer (PBL). ${ }^{10}$

In this context, few studies have been performed to predict the formation of $\mathrm{O}_{3}$ and other secondary pollutants and particularly to evaluate the insertion of new fuels into an energy matrix. Thus, this study conducts a brief overview of the computational models that have been used to predict the formation of tropospheric $\mathrm{O}_{3}$ and presents the results of previous studies to predict the formation of tropospheric $\mathrm{O}_{3}$.

\section{Atmosphere Characterization}

The Earth's atmosphere can be divided in five layers, the troposphere, stratosphere, mesosphere, thermosphere and exosphere, which are responsible for maintaining the planet's thermal equilibrium, filtering ultraviolet rays and resisting possible meteor impacts. The atmosphere is primarily composed of nitrogen (78\%) and oxygen $(21 \%)$, and the remaining $1 \%$ is mostly composed of argon $(0.93 \%)$ and carbon dioxide $(0.033 \%)$. The remaining $0.04 \%$ of the atmosphere contains all other trace gases and is where chemical changes occur. ${ }^{11}$

The troposphere is the lowest and densest layer of the atmosphere. The air pressure and temperature decrease with increasing altitude in the troposphere. Under some conditions, the temperature may not decrease with altitude; this situation is called a temperature inversion, and it is delimited by the tropopause, a zone in which the temperature stops decreasing with altitude. Most climatic phenomena occur in the troposphere, and cargo and passenger transport planes fly in this layer (Figure 1). 
The stratosphere, which is the second largest atmosphere layer, lies above the troposphere and extends up to $55 \mathrm{~km}$ above ground level. ${ }^{12}$ Unlike the troposphere, the temperature increases with increasing altitude due to solar absorption by ozone. The ozone layer is located in this layer, and the interaction between ultraviolet light, ozone and the atmosphere at that level releases heat, which heats the atmosphere and helps to create the temperature inversion in this layer. Supersonic aircraft and weather measuring balloons can reach this layer. ${ }^{13,14}$

The mesosphere contains the coldest temperatures in the Earth's atmosphere (near its top). Unlike the stratosphere, the temperature in the mesosphere decreases with increasing altitude. It is also called the meteorite shield because meteors are destroyed as a result of collisions with the gas particles. ${ }^{15}$

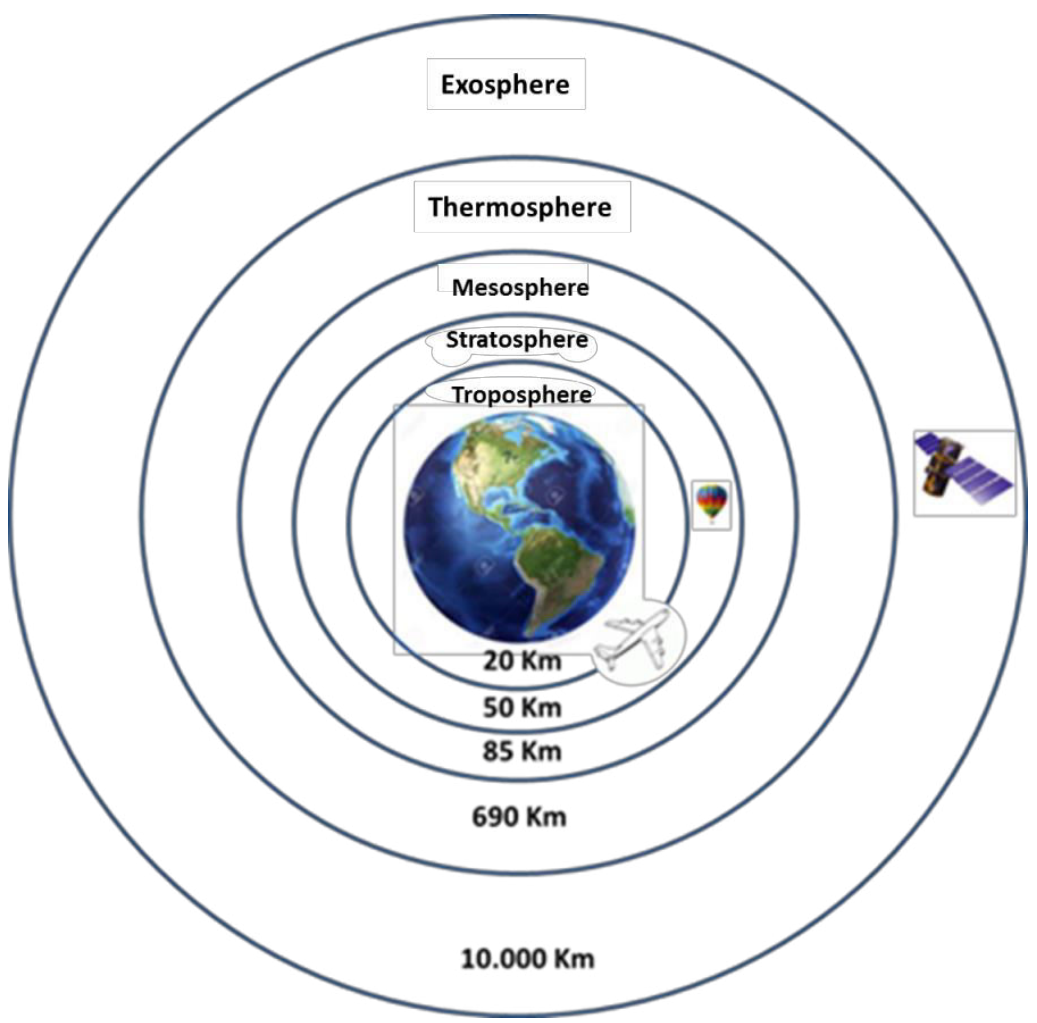

Figure 1. Layers of the Earth's atmosphere. Source: Prepared by the author

The fourth layer, the thermosphere, is located between 500 and $1,000 \mathrm{~km}$ above the ground. The ultraviolet radiation from sunlight is very intense, and it breaks down the molecules. Its temperature increases with altitude because the low oxygen fractions absorb the solar radiation. Auroras occur in this layer. ${ }^{14}$

The exosphere is the highest atmospheric layer before sidereal space, and it has no well-defined upper boundary. The air pressure in this region is very low.
Information transmission satellites and space telescopes are located in this layer.

\section{Atmospheric Pollution}

The atmosphere is constantly being chemically altered due to the various activities that can occur because of anthropogenic actions (industry, energy generation, transportation and domestic 
sources) and natural activities combined with the weather conditions. Such changes may compromise air quality and climate and may have several implications at the urban, regional and global levels. Almost 3,000 different compounds resulting from human activity, most of which are organic, have been identified in the atmosphere. ${ }^{16}$

Anthropic sources may be stationary or mobile (Figure 2). Stationary sources comprise mostly industries, which occupy a relatively limited area and allow a direct evaluation of the source. Thermoelectric plants that use coal, fuel oil or gas are also considered stationary sources. Mobile sources include automotive vehicles, trains, airplanes and maritime vessels, which make the monitoring of pollutants more complex.

The use of fossil fuels such as gasoline, diesel, natural gas and coal, which are mainly used in power generation, can generate high indices of air pollution. The levels of this type of air pollution are measured by the amount of polluting substances present in the air, and these measurements are limited to several pollutants. The measurement constraints are based on the technical capacity of monitoring and on the impact that the pollutant can have on the environment. In addition, pollutants emitted directly from their source of origin, called primary pollutants, may react with other compounds and radicals present in the troposphere and generate new compounds, which are called secondary pollutants.

The primary pollutants (carbon oxides, $\mathrm{NO}_{x}$ and sulfur oxides $\left(\mathrm{SO}_{\mathrm{x}}\right)$, alcohols, aldehydes, hydrocarbons (HC), organic acids and particulate matter (PM)) in urban environments are mainly emitted as a result of human activities associated with the production and use of energy. ${ }^{17}$ Secondary pollutants are formed in the atmosphere as a result of hydrolysis, oxidation and/or photochemical oxidation. ${ }^{18}$ The pollutants that are often found in the atmosphere include carbon monoxide (CO), $\mathrm{NO}_{\mathrm{x}}, \mathrm{SO}_{\mathrm{x}}, \mathrm{PM}$, VOC, $\mathrm{O}_{3}$ and several greenhouse gases (GHGs), such as carbon dioxide $\left(\mathrm{CO}_{2}\right)$, methane $\left(\mathrm{CH}_{4}\right)$, nitrous oxide $\left(\mathrm{N}_{2} \mathrm{O}\right)$, chlorofluorocarbons (CFCs) and nitric acid $\left(\mathrm{HNO}_{3}\right)^{16}$

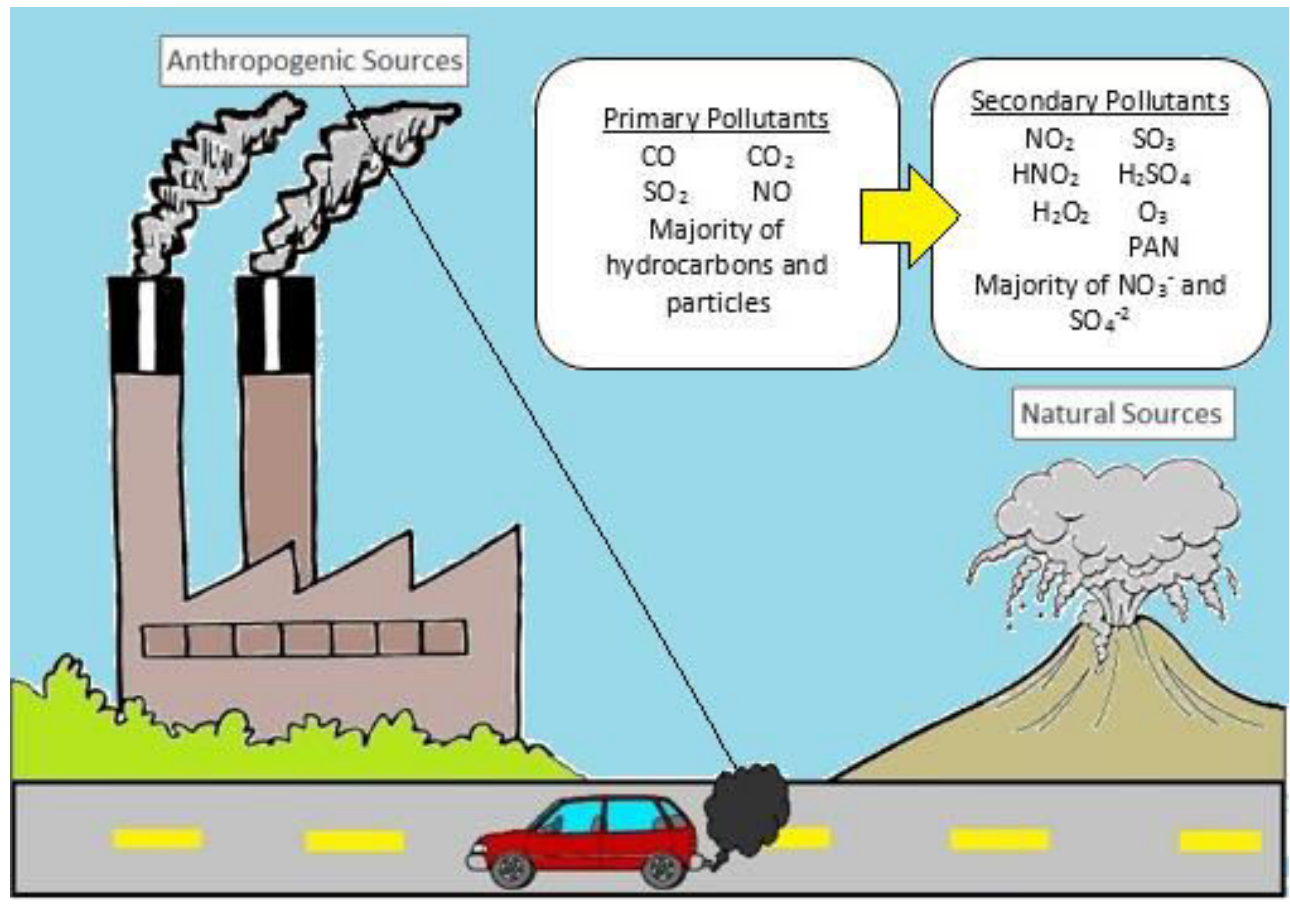

Figure 2. Sources of primary pollutants and the formation of secondary pollutants. Prepared by the author 
Air pollution results from the combination of high emissions and unfavorable climatic conditions. The most common air pollutants, which are also known as "criterion" pollutants, are used as quality indicators worldwide and include $\mathrm{PM}, \mathrm{O}_{3}, \mathrm{CO}, \mathrm{SO}_{\mathrm{x}}, \mathrm{NO}_{\mathrm{x}}$ and VOC. Table 1 describes each pollutant as well as their main sources.

Table 1. Descriptions and sources of main air pollutants

\begin{tabular}{|c|c|c|}
\hline Pollutant & Description & Source \\
\hline PM & $\begin{array}{l}\text { Particles of solid or liquid matter } \\
\text { suspended in the air in the form of } \\
\text { dust, mist, aerosol, smoke, soot etc. } \\
\text { that can stay in the air and travel long } \\
\text { distances. }\end{array}$ & $\begin{array}{l}\text { The burning of fossil fuels and plant } \\
\text { biomass, ammonia emissions from } \\
\text { agriculture, emissions from roadwork and } \\
\text { paving, secondary aerosols (formed in } \\
\text { the atmosphere) such as sulfate and } \\
\text { nitrate. }\end{array}$ \\
\hline $\mathrm{O}_{3}$ & $\begin{array}{l}\text { Harmful to air quality, outside of the } \\
\text { ozone layer. It is an important GHG, a } \\
\text { major component of photochemical } \\
\text { smog, and the primary source of } \\
\text { hydroxyl radicals which control the } \\
\text { oxidizing capacity of the troposphere. }\end{array}$ & $\begin{array}{l}\text { Not emitted directly into the } \\
\text { atmosphere. Formed through complex } \\
\text { chemical reactions that take place with } \\
\mathrm{NO}_{2} \text { and VOC in the presence of solar } \\
\text { radiation. }\end{array}$ \\
\hline $\mathrm{CO}$ & $\begin{array}{l}\text { Odorless and colorless gas formed in } \\
\text { the process of burning fuels. }\end{array}$ & $\begin{array}{l}\text { Derived from the incomplete combustion } \\
\text { in automotive vehicles in urban areas. }\end{array}$ \\
\hline $\mathrm{SO}_{\mathrm{x}}$ & $\begin{array}{l}\text { Toxic and colorless gasses mainly } \\
\text { released from the burning of fossil } \\
\text { fuels. They are an important precursor } \\
\text { of sulfates, which are a major } \\
\text { component of inhalable particles. }\end{array}$ & $\begin{array}{l}\text { Processes that burn fuel oil, oil refineries, } \\
\text { diesel vehicles, production of pulp and } \\
\text { paper, fertilizers. }\end{array}$ \\
\hline $\mathrm{NO}_{\mathrm{x}}$ & $\begin{array}{l}\text { Pollutants with highly oxidizing action; } \\
\text { their presence in the atmosphere is a } \\
\text { key factor in the formation of } \\
\text { tropospheric ozone. }\end{array}$ & $\begin{array}{l}\text { Natural: volcanism, bacterial action, } \\
\text { electric discharges; Anthropogenic: } \\
\text { combustion processes in mobile and } \\
\text { stationary sources. }\end{array}$ \\
\hline VOC & $\begin{array}{l}\text { Gases and vapors resulting from the } \\
\text { incomplete burning and evaporation } \\
\text { of fuels and other organic products. } \\
\text { Many of these compounds actively } \\
\text { participate in ozone formation } \\
\text { reactions. }\end{array}$ & $\begin{array}{l}\text { Emitted by vehicles, industries, fuel } \\
\text { storage, biogenic and transfer processes, } \\
\text { etc. }\end{array}$ \\
\hline
\end{tabular}

The main anthropogenic source responsible for urban emissions is automotive vehicles that emit toxic substances, mainly $\mathrm{CO}, \mathrm{VOC}, \mathrm{CO}_{2}$ and $\mathrm{NO}_{\mathrm{x}}$, into the atmosphere due to the combustion and incomplete burning of petroleumderived fuels. One of the consequences of the use of large quantities of automobiles is traffic jams, which increase fuel consumption and thus increase the emissions of pollutants in general. Emissions from vehicular engines may occur from the exhaust or the evaporative nature of the fuel (evaporation of the fuel in the engine and during transfer 
operations, such as storage and delivery), and they vary depending on parameters such as age, technology, size and use of the vehicle, type and quality of the fuel, maintenance and driving. In addition, particulate emissions may occur from the brakes, clutch and tire wear.

The establishment of pollution control strategies should take into account not only the primary emissions, but also the formation of secondary compounds. In this context, it is necessary to develop studies that evaluate the emissions of possible precursors $\left(\mathrm{NO}_{x}\right.$ and $\left.\mathrm{VOC}\right)$ of tropospheric $\mathrm{O}_{3}$ formation, which are mainly from identifiable specific sources, such as vehicle traffic. ${ }^{21}$ In addition, many variables can influence the increase or decrease in the concentration of tropospheric ozone, such as: weather, geography and emissions in a given location. ${ }^{17}$

The basic chemistry for the ozone formation is described in equations 1 to 3 . Photodissociation of $\mathrm{NO}_{2}$ by sunlight $(\lambda<430$ $\mathrm{nm})$ is the only significant anthropogenic source of $\mathrm{O}_{3}$ in photochemical smog: ${ }^{6}$

$$
\begin{aligned}
& \mathrm{NO}_{2}+h v \rightarrow \mathrm{NO}+\mathrm{O}\left({ }^{3} \mathrm{P}\right) \\
& \mathrm{O}\left({ }^{3} \mathrm{P}\right)+\mathrm{O}_{2}+\mathrm{M} \rightarrow \mathrm{O}_{3}+\mathrm{M} \\
& \mathrm{O}_{3}+\mathrm{NO} \rightarrow \mathrm{NO}_{2}+\mathrm{O}_{2}
\end{aligned}
$$

where $M$ is a third element (Equation 2), such as $\mathrm{N}_{2}$ or $\mathrm{O}_{2}$, that extracts the energy from the reaction and stabilizes $\mathrm{O}_{3}$.

Absorption of sunlight induces photochemistry and generates a variety of free radicals that drive the chemistry of the troposphere as well as the stratosphere. ${ }^{9}$ When VOC are present in the atmosphere, they react to form radicals, which consume $\mathrm{NO}$ or convert $\mathrm{NO}$ to $\mathrm{NO}_{2}$; this process prevents the natural reaction with $\mathrm{O}_{3}$ and causes the concentration of tropospheric $\mathrm{O}_{3}$ to increase considerably. The formation of tropospheric $\mathrm{O}_{3}$ can be directly linked to atmospheric pollution events associated with heavy vehicle traffic, especially in urban areas.

\section{Photochemical modeling to predict the formation of tropospheric ozone}

Air quality models use mathematical and numerical techniques to simulate the physical and chemical processes that affect air pollutants as they disperse and react in the atmosphere. Based on weather data and information about emission sources, such as emission rates and source height, these models are designed to characterize the primary pollutants that are emitted directly into the atmosphere and, in some cases, secondary pollutants that are formed because of complex chemical reactions within the atmosphere. ${ }^{22}$

Due to the numerous mobile and stationary sources, which make up different proportions of emissions, estimating air pollution requires computational models that include the acting atmospheric chemical processes. Photochemical models can be chosen based on the purpose of the simulation and the input data of the model. The most common photochemical models found in the literature are shown in Table 2. Most of the photochemical models are regional-scale Eulerian models, which use solutions of the diffusion-advection equation with a fixed reference system in relation to the Earth. 
Table 2. Photochemical models for air quality modeling

\begin{tabular}{|c|c|c|c|c|}
\hline Model & Acronym & Type & Scale & Ref. \\
\hline Community Multiscale Air Quality & CMAQ & Eulerian & Regional & 23 \\
\hline $\begin{array}{l}\text { Comprehensive Air Quality Model with } \\
\text { Extensions }\end{array}$ & CAMx & Eulerian & Multiscale & 24 \\
\hline Urban Airshed Model & $\begin{array}{l}\text { UAM - IV } \\
\text { UAM - V }\end{array}$ & Eulerian & Urban & 25 \\
\hline $\begin{array}{lll}\text { California/Carnegie } & \text { Institute } & \text { of } \\
\text { Technology Model } & & \end{array}$ & $\mathrm{CIT}$ & Eulerian & Urban & 25 \\
\hline $\begin{array}{l}\text { California Air Resources Board Grid } \\
\text { Model }\end{array}$ & CALGRID & Eulerian & Urban & 26 \\
\hline Gas and Aerosol Transport and Reaction & GATOR & Eulerian & Urban & 27 \\
\hline Empirical Kinetics Modeling Approach & EKMA & Box Model & Urban & 28 \\
\hline Isopleth Plotting Package Research & OZIPR & Box Model & Urban & 29 \\
\hline Sulfur Transport and Emissions Model & $\begin{array}{l}\text { STEM } \\
\text { STEM II }\end{array}$ & Eulerian & Regional & 30 \\
\hline Regional Acid Deposition Model & RADM & Eulerian & Regional & 31 \\
\hline Regional Oxidant Model & ROM & Eulerian & Regional & 32 \\
\hline $\begin{array}{l}\text { European Monitoring and Evaluation } \\
\text { Programme Oxidant }\end{array}$ & $\begin{array}{l}\text { EMEP } \\
\text { Ozone } \\
\text { Model }\end{array}$ & Eulerian & Regional & 33 \\
\hline European Air Dispersion Model & EURAD & Eulerian & Regional & 34 \\
\hline Long Term Ozone Simulation Model & LOTOS & Eulerian & Regional & 35 \\
\hline
\end{tabular}

Air quality models are computerized representations of the processes responsible for air pollution, including ozone formation, and they are heavily climate dependent and sensitive to climate change. They simulate the atmosphere at different degrees of detail by mathematically representing emissions of the initial chemical species and boundary concentrations, the chemical reactions of the species emitted and their products, and local weather, such as sunlight, wind and temperature. ${ }^{36}$ Photochemical models are based on the resolution of the same species conservation equation that describes the formation, transportation, and destination of air pollutants, including components for processing emissions, weather, topography, air quality and chemical observations. ${ }^{37}$ Most models use one of two deterministic approaches: Lagrangian or Eulerian. Sharma et al. $^{38}$ describe in detail the differences between these approaches in air quality models. In summary, photochemical models that use the Lagrangian approach are mostly intended for shorter-range simulations than Eulerian models, which provide a finer 
resolution and require greater data processing power.

Eulerian or grid models require detailed descriptions of the weather processes and transport, and the predicted concentrations are defined based on geography and the time domain and can simulate multi-day scenarios. The disadvantages are that they are expensive to maintain and run, and they require large sets of input data, which make it difficult to determine the causes and effects because of the interactions between multiple types of data. They are also limited to condensed chemical mechanisms because of the number of computational processes that must be performed. ${ }^{36}$

Lagrangian models are similar to box models in that they define a region of air as a box containing an initial concentration of pollutants. ${ }^{39}$ They are called path models because they simulate a well-mixed air column that varies vertically from the ground to the height of the boundary layer with no horizontal expansion. This air column moves along a specified wind path..$^{40}$ In box models, advection and dispersion are considered to be negligible. ${ }^{36}$

\subsection{Path Model - Box Models}

The adequacy of a photochemical model is assessed by its ability to estimate the magnitude, time and location of the occurrence of secondary pollutants. ${ }^{41} \mathrm{~A}$ simple way to predict the concentration of pollutants is through box models, where the mass of air in a region is treated as a box in which the contaminants are emitted and undergo chemical reactions. These models are based on the mass conservation equation and include chemical submodels. They have the advantage of not requiring detailed emissions, weather and air quality data that are required by other model types. ${ }^{9}$

For example, the Ozone Isopleth Plotting Package (OZIPP) is a one-dimensional path model that allows the simulation of complex chemistry with the physical processes that occur in the lower atmosphere. ${ }^{29}$ The Isopleth Plotting Package Research (OZIPR) is the OZIPP's guided research version and uses the same mechanism but acts as a more comprehensive research tool for regulatory agencies and model developers. OZIPR is computer software that was developed in FORTRAN and works on PC DOS version 2.0 or higher. In addition to the individual path simulations, the program can use the Empirical Kinetic Modeling Approach (EKMA) procedure to automatically estimate the reduction and type of precursor emissions required to achieve a specified ozone level. ${ }^{29}$

The United States Environmental Protection Agency (US EPA) model allows the simulation of ozone formation and other secondary pollutants in the atmosphere and also calculates the maximum concentrations of precursors with weather, transport, and emissions parameters from an initial data set. Using these results, it is possible to obtain the ozone isopleths, which are given as a function of the curves of the same concentration of ozone in relation to the concentrations of $\mathrm{NO}_{x}$ and $\mathrm{VOC}$ in a given environment. ${ }^{17}$

The OZIPR model can be described as an air column that covers the studied area up to the atmospheric mixing layer, such as a box with a movable lid, which is a function of the height of the mixing layer during the day (Figure 3). The entire box is considered to be perfectly homogeneous and moves along the wind path without horizontal expansion. ${ }^{42}$ The model assumes that the simulated day has an incident sun with no clouds and no rainfall. 


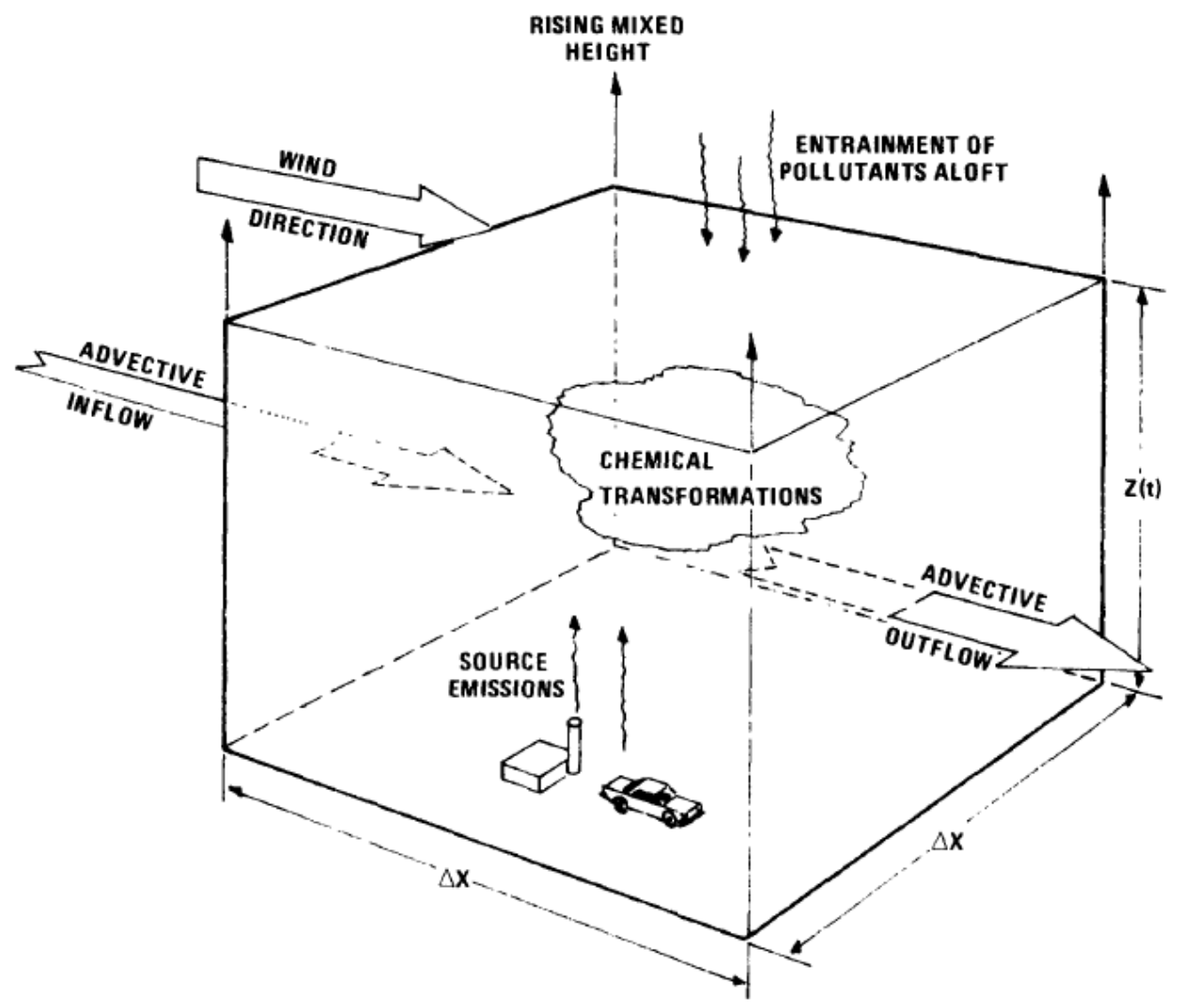

Figure 3. Schematic of the OZIPR model ${ }^{43}$

The input data of the model are entered every hour and for a single day. The city data that are necessary to run the model include the name, latitude, longitude, Greenwich Mean Time, year, month and day, starting and ending time of the simulation (usually from 6 am to $6 \mathrm{pm}$, which is when the sun is active), the initial emissions of $\mathrm{VOC}, \mathrm{NO}_{\mathrm{x}}$ and $\mathrm{CO}$, and which pollutants formations are to be calculated. The required weather parameters include the initial and final heights of the boundary mixing layer, the time the mixing layer starts and ends, temperatures, humidity, the mixing layers during the day per hour and the atmospheric pressure.

The OZIPR software and the implementation guide are available from the U.S. EPA and can be found on the internet at the U.S. EPA website. It includes several files that allow the study location data and all of the chemical data to be included in the simulation. Very complex chemical mechanisms can be used with OZIPR to describe the chemical processes that occur combined with the air mass modeling. OZIPR allows the VOC to be grouped into a single set of organic products. ${ }^{29}$

Some OZIPR applications can be cited to illustrate their importance and accuracy. OZIPIR has also been used to quantitatively assess and determine the relative importance of non-methane hydrocarbons (NMHCs) and $\mathrm{NO}_{x}$ in the formation of $\mathrm{O}_{3}$ in a petrochemical industrial city in northwest China. Although the model sometimes overestimates or underestimates the $\mathrm{O}_{3}$ concentrations, the modeled concentrations generally agree reasonably well with the monitored data. ${ }^{44}$

With the changes in fuel blends required by the Thai government by 2012, the OZIPR model was used in studies to provide a reasonable indication of the air quality resulting from the replacement of $10 \%$ of 
fuels by biofuels (biodiesel and gasohol). The simulated model data were compared to the $\mathrm{O}_{3}, \mathrm{NO}$, and $\mathrm{NO}_{2}$ concentration data from air monitoring stations operated by the Pollution Control Department of Thailand. The results showed that a $10 \%$ replacement by biofuels will lead to a maximum increase in $\mathrm{O}_{3}$ of $16 \%$ over the four simulated days compared to a $48 \mathrm{ppb}$ increase due to the expected increase in vehicle fleet size between 2006 and $2012 .^{45}$

In Brazil, five base cases were created to verify the variation in the maximum ozone concentration and thus determine the ozone formation potential of each VOC, because the ozone concentration in São Paulo exceeds the national air quality standards on several days of the year. The analysis of the results showed that the most common compounds among the ten main ozone precursors found in São Paulo using the reactivity scales created were: formaldehyde, acetaldehyde, propene, isoprene, cis-2-butene, and trans-2butene, and formaldehyde was the main ozone precursor compound. ${ }^{42}$

The atmospheric boundary layer is a crucial input parameter in air pollution models because it is not a directly measurable variable; therefore, there is great uncertainty in its estimation. A study in India approached this problem using OZIPR as a real-time mixing height model to predict ozone concentrations. The ozone concentrations predicted by the real-time mixing height model in conjunction with OZIPR showed a $13 \%$ improvement compared to those estimated from the usual extrapolated radiosonde values. ${ }^{46}$

\subsection{Chemical Mechanism}

One of the most critical components of air quality modeling is the chemical mechanism. A good simulation, prediction, and analysis of the atmosphere depend on how well these mechanisms, through their reactions, can describe the chemical processes in the environment. The main chemical mechanisms currently used in air quality modeling were developed primarily to address episodes of high levels of ozone and were rigorously evaluated for this purpose. ${ }^{47}$ A fully explicit mechanism to represent atmospheric chemical gas phase reactions contains more than 20,000 reactions and several thousand species. Consequently, even developers of highly detailed reaction mechanisms adopt a procedure to limit the size. ${ }^{48}$

Several chemical mechanisms are currently available, and they depend on the level of chemical detail required in a particular application. The main models include the Carbon Bond Model (CBM), the Acid Deposition Model, version 2 (RADM2), the Co-operative Program for monitoring and Evaluation of the Long-Range Transmission of Air Pollutants in Europe (EMEP), the Regional Atmospheric Chemistry Mechanism (RACM) and the Statewide Air Pollution Research Center (SAPRC).

Table 4 shows the chemical mechanisms most commonly used in conjunction with the previously presented photochemical models. Some of these mechanisms can only be used at regional scales, such as RADM, RACM, and SAPRC. The MCM, CRI, SAPRC, RACM and CB5 models contain the most species and reactions.

MCM has nearly 5900 species and 13,500 reactions for the detailed mechanism (MCMv3.1). ${ }^{62}$ This MCM mechanism requires more computational processing than the other mechanisms when it is combined with ozone formation and transport models, which makes the simulation very timeconsuming. Therefore, simulating the formation of secondary pollutants in a large number of scenarios takes a long time to obtain the results. Depending on the study, other more specific mechanisms can be used because the chemical processes/reactions that do not significantly change the result can be removed, which reduces the required computational processing. 
Table 4. Chemical mechanisms most commonly used in conjunction with the photochemical models

\begin{tabular}{|c|c|c|c|c|}
\hline Model & Acronym & Reactions & Species & Ref. \\
\hline \multirow{3}{*}{ Regional Acid Deposition Model } & RADM & - & 40 & 49 \\
\hline & & & & \\
\hline & RADM2 & 156 & 63 & 50 \\
\hline $\begin{array}{lll}\text { Regional } & \text { Atmospheric } & \text { Chemistry } \\
\text { Mechanism } & & \end{array}$ & RACM & 237 & 77 & 51 \\
\hline \multirow{2}{*}{ Chemical Bond Mechanism } & CB4 / CB-IV / CBM-IV & 81 & 33 & 52 \\
\hline & CB5 / CB-V / CBM-V & 156 & 51 & 53 \\
\hline Moca-ref & CV-MOCA2.2 & 66 & 41 & 54 \\
\hline \multirow{3}{*}{ Common Representative Intermediates } & CRIv2 & 1183 & 434 & \multirow{3}{*}{55} \\
\hline & & & & \\
\hline & CRIv2 - R5 & 555 & 196 & \\
\hline \multirow{3}{*}{ Statewide Air Pollution Research Center } & SAPRC-90 & $\sim 158$ & 54 & 56 \\
\hline & SAPRC-99 & 198 & 72 & 57 \\
\hline & SAPRC-07 & 339 & 119 & 58 \\
\hline Lurmann, Carter and Coyner & LCC & 189 & - & 59 \\
\hline Master Chemical Mechanism & MCMv3.1 & 13,500 & 5900 & 60 \\
\hline $\begin{array}{l}\text { European Monitoring and Evaluation } \\
\text { Program }\end{array}$ & EMEP & 148 & 79 & 61 \\
\hline
\end{tabular}

Among the photochemical modeling studies in the last five years, we highlight those that analyzed, studied and estimated the air quality in different regions. The CMAQ model with the Weather Research and Forecasting (WRF) model has been used more frequently in recent years because it can be applied for research as well as for operational forecasting applications. This module is widely used when no weather data are available for a region.

CMAQ is an active open source threedimensional model from the U.S. EPA and is dependent on a weather module for air quality modeling. Depending on the application, as in the case of obtaining emissions data, it is also necessary to add an emissions input module, such as Sparse Matrix Operator Kernel Emissions (SMOKE), to estimate the magnitudes and locations of pollution sources. This implies the need for greater data processing (i.e., more computational resources are needed), which requires high-performance computers. In addition, these modules require inventories with data from the region, which are not always available for some countries.

The sensitivity of tropospheric ozone to 
varying emissions of precursors from different species and contributing sources in India was analyzed using the WRF-CMAQ model. This study used the WRF modeling system (3.4.1) and Model-3/CMAQ version 4.7.1 to simulate the weather and air quality parameters, respectively. The baseline CMAQ model runs were performed for 2010, and the ozone concentrations were validated with observed data sets from six monitoring sites in India. The authors concluded that reducing $\mathrm{NO}_{x}$ emissions on a regional scale can reduce ozone concentrations in India. The sector sensitivity analysis showed that the transportation sector has the highest potential for controlling ozone pollution in India, followed by the industrial sector. ${ }^{63}$

A study was performed in Taiwan in which researchers studied the potential impacts of the use of $100 \%$ electric vehicles on air quality (gaseous and particulate pollutants) using CMAQ version 4.7.1 and WRF. The study also assumed that the power supply was transferred to coal-fired power plants or clean energy sources. The authors observed that CO, VOC, $\mathrm{NO}_{\mathrm{x}}$ and $\mathrm{PM}_{2.5}$ emissions in Taiwan from road sources would decrease by 1500 (85\%), 165 (79\%), $33.9(27 \%)$ and 7.2 (27\%) $\mathrm{Gg} /$ year, respectively. However, $\mathrm{NO}_{x}$ and $\mathrm{SO}_{2}$ emissions from the electricity sector would increase by up to $20.3(29 \%)$ and 12.9 $(29 \%) \mathrm{Gg} /$ year, respectively, if all of the electricity was supplied by thermoelectric plants. ${ }^{64} \mathrm{~A}$ study predicted ozone levels in addition to other pollutants using WRF/Chem-MADRID with three different gas phase mechanisms: a standard mechanism (CBM-Z) and two new mechanisms (CB05 and SAPRC-99). This helped to address the problems of examining the impacts of different gas phase mechanisms on WRF forecasts and identifying important sources of uncertainty in the modeling of weather, chemistry and their interactions through several feedback mechanisms with future model improvements. The study concluded that the $\mathrm{CB} 05$ simulation provided the best general predictions for $\mathrm{CO}, \mathrm{O}_{3}$, and $\mathrm{PM}_{2.5}$ concentrations, and $\mathrm{CBM}-\mathrm{Z}$ provided the best overall predictions for $\mathrm{SO}_{2}$ and $\mathrm{NO}_{2}$, and SAPRC-99 provided the best general predictions of $\mathrm{HNO}_{3}$. The simulation with SAPRC-99 predicted higher levels of $\mathrm{O}_{3}$ and $\mathrm{NO}_{2}$ than those with the other two gas phase mechanisms. $^{65}$ Among the chemical mechanisms described above, SAPRC is a frequently updated clustered species mechanism that was developed for urbanscale studies. It has been used to develop a VOC reactivity scale to derive exhaust standards for alternative fuel vehicles. ${ }^{66,67}$ The rates and reactions included in this mechanism are constantly updated based on the current state of the science. VOC emissions often need to be compressed or "grouped" into species classes for use in emissions inventories for air quality modeling to ensure computational efficiency. ${ }^{68}$

SAPRC has been updated several times. Its first version in 1990 was called SAPRC- $90^{56}$, and it was later upgraded to the second version in 2000, which was called SAPRC-99. ${ }^{57}$ The third version, SAPRC07, was developed by $\mathrm{Carter}^{57}$ in 2010. Currently, a version called SAPRC-11 is being finalized for gas phases only. Some versions of SAPRC have an adjustable number of species to represent organic species, and these may become very explicit. ${ }^{69}$ Researchers use several of these versions and have made their own modifications to the mechanism. ${ }^{17}$

In the United States, a study evaluated SAPRC07T with the CMAQ air quality model for simulations of two periods in order to find a balance between the representation of atmospheric chemistry complexity, the maintenance of computational efficiency and the reproduction of observed concentrations of pollutants. Species were added to SAPRC07 for Aromatic Polycyclic Hydrocarbons (HPA), which are specific precursors of ozone and secondary aerosol production, and were compared to the SAPRC-99 mechanism. The SAPRC07T model generally predicted lower ozone concentrations than the SAPRC-99 model. $^{70} \mathrm{~A}$ U.S. article compared five chemical mechanisms (RACM, CB05, LaRC, SAPRC-99, SAPRC-07 and MCM v3.1) using the same database. The concentrations of hydroxyl $(\bullet \mathrm{OH})$ and hydroperoxyl $(\mathrm{HOO} \bullet)$ radicals in 
the study were calculated with a zero dimension box model with each mechanism and then compared with the measured $\bullet \mathrm{OH}$ and HOO• concentrations. The results showed that the modeled $\bullet \mathrm{OH}$ and $\mathrm{HOO} \bullet$ concentrations were lower than the measured values. $^{71}$

The most common mechanisms are currently the SAPRC and the Carbon Bond (CB). The CB-IV and SAPRC99 photochemical mechanisms were compared under conditions relevant to southeastern Texas using the CAMx model. A preliminary assessment of ozone concentrations predicted by the mechanisms showed a significant difference: SAPRC predicted ozone concentrations as much as 45 ppb higher than CB-IV. The differences between SAPRC99 and CB-IV could at least partially be attributed to the combined effects of the differences in the chemical substances of the aromatic compounds and free radicals. ${ }^{72}$

The impacts of formaldehyde and acetaldehyde concentrations on air quality monitoring over five years were evaluated using OZIPR combined with SAPRC by Correa. $^{73}$ A total of 183 samples were collected from 2004 to 2009. The OZIPR model with SAPRC was used to describe a base case scenario to examine the change in ozone formation with changing input parameters (mainly formaldehyde and acetaldehyde). Orlando studied ozone precursors in the Metropolitan Region of São Paulo (RMSP) with the OZIPR model and the SAPRC mechanism. ${ }^{42}$ Corrêa and Arbilla used the results of a simulation with OZIPR and SAPRC to confirm that high levels of acetaldehyde on a high-traffic street in Rio de Janeiro could be attributed to the direct emissions of the vehicle fleet and the oxidation of VOC initiated by photochemistry. $^{74}$

\section{Final Considerations}

This article has developed a critical analysis of the photochemical models that have been used to predict the formation of tropospheric ozone. Among the available models can be highlighted the OZIPR combined with SAPRC kinetic module. Some applications of this photochemical model have been described comparing the prediction of tropospheric ozone formation with local data sampled, and the results showed that there were significant correlations. In this way, it is possible to predict and propose public mitigation policies for this secondary pollutant, aiming to improve the air quality of large urban centers.

Thus, to select a photochemical model that describes the formation of photochemical oxidants, such as ozone, in a given region, a diagnosis of the region is needed to identify the precursor sources to be used as input data. In addition, air quality monitoring data and adjustments to the atmospheric chemistry of the region (through experimental tests or emission inventories) are used as input data. In this sense, it is important to know the input data required to run the model to determine if they match the data obtained from the region to be modeled. The choice of the model to be used depends on the available computational capacity and the information required as input data for modeling.

\section{Acknowledgements}

The authors are grateful to the Financier of Studies and Projects (Financiadora de Estudos e Projetos - FINEP), the Brazilian Federal Agency for the Support and Evaluation of Graduate Education (Conselho Nacional de Desenvolvimento Científico e Tecnológico - CNPq), the Coordination for the Improvement of Higher Level Personnel (Coordenação de Aperfeiçoamento de Pessoal de Nível Superior - CAPES) and the PRH55 ANP SENAI CIMATEC. 


\section{References}

${ }^{1}$ Arbex, M. A.; de Paula Santos, U.; Martins, L. C.; Saldiva, P. H. N.; Pereira, L. A. A.; Braga, A. L. F. A poluição do ar e o sistema respiratório. Jornal Brasileiro de Pneumologia 2012, 38, 643. [CrossRef]

${ }^{2}$ Ministério do Meio Ambiente - MMA. [s.d.]. Disponível em: <http://www.mma.gov.br/> Acesso em: 31 agosto 2017.

${ }^{3}$ Miranda, A. I.; Martins, H.; Valente, J.; Amorim, J. H.; Borrego, C.; Tavares, R.; Samson, R.; del Amo, R. A. Em Future City Springer International Publishing, 2017.

${ }^{4}$ Silva, K. C. C.; Daemme, L. C.; Macedo, V.; Penteado, R.; Corrêa, S. M. Em Anais do XXII Simpósio Internacional de Engenharia Automotiva Editora Edgard Blücher, 2014.

${ }^{5}$ Companhia de Tecnologia e Saneamento Ambiental (CETESB) Ficha de informação toxicológica: Formaldeído e Acetaldeído. Divisão de toxicologia, genotoxidade e microbiologia ambiental. [s.d.]. Disponível em:

<http:/www.cetesb.sp.gov.br/tecnologiaambiental/laboratorios/109-informacoestoxicologicas> Acesso em: 17 de junho de 2017.

${ }^{6}$ Finlayson-Pitts, B. J.; Jr., J. N. P. Atmospheric Chemistry of Tropospheric Ozone Formation: Scientific and Regulatory Implications. Air Waste 1993, 43, 1091. [CrossRef].

${ }^{7}$ Drumm, F. C.; Gerhardt, A. E.; Fernandes, G. D.; Chagas, P.; Sucolotti, M. S.; Kemerich, P. D. D. C. Poluição atmosférica proveniente da queima de combustíveis derivados do petróleo em veículos automotores. Revista Eletrônica em Gestão, Educação e Tecnologia Ambiental 2014, 18, 1. [CrossRef]

${ }^{8}$ Chang, P.; Xu, G. A review of the health effects and exposure-responsible relationship of diesel particulate matter for underground mines. Internation Journal Min Science Technology 2017, 27, 831. [CrossRef]

${ }^{9}$ Finlayson-Pitts, B. J.; Pitts Jr, J. N. Chemistry of the upper and lower atmosphere: theory, experiments, and applications Academic press, 1999.

10 Balbino, H. T. Dissertação de mestrado.
Universidade de São Paulo, 2008. [Link]

${ }^{11}$ Mcdonald, K. Air pollution in the urban atmosphere: sources and consequences. Em Metropolitan Sustainability Understanding and Improving the Urban Environment 2012, 231. [CrossRef]

12 Seinfeld, J. H.; Pandis, S. N. Atmospheric chemistry and physics: from air pollution to climate change John Wiley \& Sons, 2016.

${ }^{13}$ Almeida, H. A. de Cimatologia aplicada à geografia. 2016, [Link]

${ }^{14}$ Lannes, J. B.; others Os planetas do Sistema Solar. 2005.

${ }^{15}$ Barry, R. G.; Chorley, R. J. Atmosfera, tempo e clima Bookman Editora, 2009.

${ }^{16}$ Guarieiro, L. L. N.; Guarieiro, A. L. N. Em Biofuels - Economy, Environment and Sustainability InTech, 2013.

${ }^{17}$ Arbilla, G.; de Oliveira, K. M. P. G. Otimização de um mecanismo fotoquímico para a simulação da atmosfera urbana brasileira. Quimica Nova 1999, 22, 790. [CrossRef]

${ }^{18}$ Armenta, S.; de la Guardia, M. Pollutants and Air Pollution. Comprehensive Analytical Chemistry. 2016, 73, 27. [Link]

${ }^{19}$ Mclntosh, A.; Pontius, J. Science and the Global Environment: Case Studies for Integrating Science and the Global Environment Elsevier, 2016.

${ }^{20}$ Ehhalt, D.; Prather, M.; Dentener, F.; Derwent, R.; Dlugokencky, E. J.; Holland, E.; Isaksen, I.; Katima, J.; Kirchhoff, V.; Matson, P.; others Atmospheric chemistry and greenhouse gases 2001.

${ }^{21}$ Kumar, U.; Prakash, A.; Jain, V. K. A Photochemical Modelling Approach to Investigate $\mathrm{O} 3$ Sensitivity to NOx and VOCs in the Urban Atmosphere of Delhi. Aerosol Air Quality Research 2008, 8, 147. [CrossRef]

${ }^{22}$ EPA Support Center for Regulatory Atmospheric Modeling (SCRAM). [s.d.]. Disponível em: <https://www.epa.gov/scram/air-qualitymodels.> Acessado em: 03 de Junho de 2017 ${ }^{23}$ Byun, D. W.; Ching, J. K. S.; others Science algorithms of the EPA Models-3 community multiscale air quality (CMAQ) modeling system US Environmental Protection Agency, Office of Research and Development Washington, DC, 1999. 
${ }^{24}$ Reynolds, S.; Roth, P. Em Report from the EPA Source Attribution Workshop 1997.

${ }^{25}$ McRae, G. J.; Goodin, W. R.; Seinfeld, J. H. Mathematical modeling of photochemical air pollution. 1982.

${ }^{26}$ Yamartino, R. J.; Scire, J. S.; Carmichael, G. R.; Chang, Y. S. The CALGRID mesoscale photochemical grid model-I. Model formulation. Atmospheric Environmental Part A. Gen. Top. 1992, 26, 1493.

${ }^{27}$ Lu, R.; Turco, R. P.; Jacobson, M. Z. An integrated air pollution modeling system for urban and regional scales: 1 . Structure and performance. Journal Geophysical Research Atmospheric 1997, 102, 6063. [CrossRef]

${ }^{28}$ Council, N. R.; others Rethinking the ozone problem in urban and regional air pollution National Academies Press, 1992.

${ }^{29}$ Gery, M. W.; Crouse, R. R. User's guide for executing OZIPR. US Environmental Protection Agency, Atmospheric Research and Exposure Assessment Laboratory, 1a. ed. US Environ. Prot. Agency, Atmos. Res. Expo. Assess. Lab. 1a. ed. 1991.

${ }^{30}$ Carmichael, G. R.; Peters, L. K.; Saylor, R. D. The STEM-II regional scale acid deposition and photochemical oxidant model-I. An overview of model development and applications. Atmospheric Environmental Part A. Gen. Top. 1991, 25, 2077.

${ }^{31}$ Chang, J. S.; Brost, R. A.; Isaksen, I. S. A.; Madronich, S.; Middleton, P.; Stockwell, W. R.; Walcek, C. J. A three-dimensional Eulerian acid deposition model: Physical concepts and formulation. Journal Geophysical Research Atmospheric 1987, 92, 14681. [CrossRef]

${ }^{32}$ Lamb, R. A regional-scale $(1000 \mathrm{~km})$ model of photochemical air pollution $\mathrm{C} 1$. Theoretical formulation. EPA Rep. No. EPA-600/3-83-035. US Environ. Prot. Agency, Res. Triangle Park. North Carolina. [s.d.]. [Link]

${ }^{33}$ Simpson, D. Long-period modelling of photochemical oxidants in Europe. Model calculations for July 1985. Atmospheric Environmental Part A. Gen. Top. 1992, 26, 1609.

${ }^{34}$ Hass, H. Description of the EURAD chemistry transport module (CTM) version 2. Report 1991, 83,.

${ }^{35}$ Builtjes, P. J. H. The LOTOS-Long Term
Ozone Simulation Project: Summary Report TNO Institute of Environmental Sciences, 1992.

${ }^{36}$ Tonnesen, G.; Olaguer, J.; Bergin, M.; Russell, T.; Hanna, A.; Makar, P.; Derwent, D.; Wang, Z. Air quality models. Relat. React. Work. Group, NASCO, Pasco,(Draft as 11/26/98, pp 55) 1998.

${ }^{37}$ Russell, A. NARSTO critical review of photochemical models and modeling. Atmospheric Environmental 2000, 34, 2283. [CrossRef]

${ }^{38}$ Sharma, S.; Sharma, P.; Khare, M. Photochemical transport modelling of tropospheric ozone: A review. Atmospheric Environmental 2017, 159, 34. [CrossRef]

${ }^{39}$ Holmes, N. S.; Morawska, L. A review of dispersion modelling and its application to the dispersion of particles: An overview of different dispersion models available. Atmospheric Environmental 2006, 40, 5902. [CrossRef]

${ }^{40}$ Stein, A. F.; Lamb, D. The sensitivity of sulfur wet deposition to atmospheric oxidants. Atmospheric Environmental 2000, 34, 1681. [CrossRef]

${ }^{41}$ Boubel, R. W.; Vallero, D.; Fox, D. L.; Turner, B.; Stern, A. C. Fundamentals of air pollution Elsevier, 2013.

${ }^{42}$ Orlando, J. P.; Alvim, D. S.; Yamazaki, A.; Corrêa, S. M.; Gatti, L. V. Ozone precursors for the São Paulo Metropolitan Area. Science Total Environmental 2010, 408, 1612. [CrossRef]

${ }^{43}$ Schere, K. L.; User's guide for the photochemical box model (PBM). EPA 1984

${ }^{44}$ Jia, C.; Mao, X.; Huang, T.; Liang, X.; Wang, Y.; Shen, Y.; Jiang, W.; Wang, H.; Bai, Z.; Ma, M.; Yu, Z.; Ma, J.; Gao, H. Non-methane hydrocarbons (NMHCs) and their contribution to ozone formation potential in a petrochemical industrialized city, Northwest China. Atmospheric Environmental 2016, 169, 225. [CrossRef]

${ }^{45}$ Milt, A.; Milano, A.; Garivait, S.; Kamens, R. Effects of $10 \%$ biofuel substitution on ground level ozone formation in Bangkok, Thailand. Atmospheric Environmental 2009, 43, 5962. [CrossRef]

${ }^{46}$ Nath, S.; Patil, R. S. Prediction of air 
pollution concentration using an in situ real time mixing height model. Atmospheric Environmental 2006, 40, 3816. [CrossRef]

${ }^{47}$ Kaduwela, A.; Luecken, D.; Carter, W.; Derwent, R. New directions: Atmospheric chemical mechanisms for the future. Atmospheric Environmental 2015, 122, 609. [CrossRef]

${ }^{48}$ Dodge, M. Chemical oxidant mechanisms for air quality modeling: critical review. Atmospheric Environmental 2000, 34, 2103. [CrossRef]

${ }^{49}$ Stockwell, W. R. A homogeneous gas phase mechanism for use in a regional acid deposition model. Atmospheric Environmental 1986, 20, 1615. [CrossRef]

${ }^{50}$ Stockwell, W. R.; Middleton, P.; Chang, J. $S . ;$ Tang, $X$. The second generation regional acid deposition model chemical mechanism for regional air quality modeling. Journal Geophysical Research Atmospheric 1990, 95, 16343. [CrossRef]

${ }^{51}$ Stockwell, W. R.; Kirchner, F.; Kuhn, M.; Seefeld, S. A new mechanism for regional atmospheric chemistry modeling. J. Geophys. Res. Atmos. 1997, 102, 25847. [CrossRef]

${ }^{52}$ Gery, M. W.; Whitten, G. Z.; Killus, J. P.; Dodge, M. C. A photochemical kinetics mechanism for urban and regional scale computer modeling. Journal Geophysical Research Atmospheric 1989, 94, 12925. [CrossRef]

${ }^{53}$ Yarwood, G.; Rao, S.; Yocke, M.; Whitten, G. Updates to the carbon bond chemical mechanism: CB05 final report to the US EPA. $R T-0400675$ 2005, [Link]

${ }^{54}$ Arteta, J.; Cautenet, S.; Taghavi, M.; Audiffren, N. Impact of two chemistry mechanisms fully coupled with mesoscale model on the atmospheric pollutants distribution. Atmospheric Environmental 2006, 40, 7983. [CrossRef]

${ }^{55}$ Jenkin, M. E.; Watson, L. A.; Utembe, S. R.; Shallcross, D. E. A Common Representative Intermediates (CRI) mechanism for VOC degradation. Part 1: Gas phase mechanism development. Atmospheric Environmental 2008, 42, 7185. [CrossRef]

${ }^{56}$ Carter, W. P. L. A detailed mechanism for the gas-phase atmospheric reactions of organic compounds. Atmospheric
Environmental Part A. Gen. Top. 1990, 24, 481. [CrossRef]

${ }^{57}$ Carter, W. P. L. Documentation of the SAPRC-99 chemical mechanism for VOC reactivity assessment. Contract 2000, 92, 95.

${ }^{58}$ Carter, W. P. L. . Development of the SAPRC-07 chemical mechanism. Atmospheric Environmental 2010, 44, 5324. [CrossRef]

${ }^{59}$ Lurmann, F. W. A surrogate species chemical reaction mechanism for urban-scale air quality simulation models. EPA/600/387/014 1987.

${ }^{60}$ Jenkin, M. E.; Saunders, S. M.; Pilling, M. J. The tropospheric degradation of volatile organic compounds: a protocol for mechanism development. Atmospheric Environmental 1997, 31, 81. [CrossRef]

${ }^{61}$ Simpson, D.; Ashmore, M.; Emberson, L.; Tuovinen, J.-P.; MacDougall, M.; Smith, R. I. Stomatal ozone uptake over Europe: preliminary results. SWEDISH WATER AIR Pollution Research Laboratory B 2003, 66.

62 Karamchandani, P.; Zhang, Y.; Chen, S.; BalmoriltextendashBronson, R. Development of an extended chemical mechanism for global-through-urban applications. Atmospheric Pollution Research 2012, 3, 1. [CrossRef]

${ }^{63}$ Sharma, S.; Chatani, S.; Mahtta, R.; Goel, A.; Kumar, A. A. Sensitivity analysis of ground level ozone in India using WRF-CMAQ models. Atmospheric Environmental 2016, 131, 29. [CrossRef]

${ }^{64}$ Li, N.; Chen, J.-P.; Tsai, I.-C.; He, Q.; Chi, S.Y.; Lin, Y.-C.; Fu, T.-M. Potential impacts of electric vehicles on air quality in Taiwan. Science Total Environmental 2016, 566, 919.

${ }^{65}$ Zhang, Y.; Chen, Y.; Sarwar, G.; Schere, K. Impact of gas-phase mechanisms on Weather Research Forecasting Model with Chemistry (WRF/Chem) predictions: Mechanism implementation and comparative evaluation. Journal Geophysical Research Atmospheric 2012, 117, 1. [CrossRef]

${ }^{66}$ Mobile Source Division Research Division, S. S. D.; Technical Support Division California Air Resources Board, S. C. Low-emission vehicles/clean fuels - Technical Support Document. 1990, [Link]

${ }^{67}$ Mobile Source Division Research Division, S. of C. A. R. B. Proposed reactivity 
adjustment factors for transitional lowemissions vehicles: Technical Support Document. 1991. [Link]

${ }^{68}$ Roy, A.; Choi, Y. Effect of ambient temperature on species lumping for total organic gases in gasoline exhaust emissions. Atmospheric Environmental 2017, 152, 240. [CrossRef]

${ }^{69}$ Calvert, J. G.; Orlando, J. J.; Stockwell, W. R.; Wallington, T. J. The mechanisms of reactions influencing atmospheric ozone Oxford University Press, 2015.

${ }^{70}$ Hutzell, W. T.; Luecken, D. J.; Appel, K. W.; Carter, W. P. L. Interpreting predictions from the SAPRCO7 mechanism based on regional and continental simulations. Atmospheric Environmental 2012, 46, 417. [CrossRef]

${ }^{71}$ Chen, S.; Ren, X.; Mao, J.; Chen, Z.; Brune, W. H.; Lefer, B.; Rappenglück, B.; Flynn, J.; Olson, J.; Crawford, J. H. A comparison of chemical mechanisms based on TRAMP-2006 field data. Atmospheric Environmental 2010, 44, 4116. [CrossRef]

${ }^{72}$ Faraji, M.; Kimura, Y.; McDonald-Buller, E.; Allen, D. Comparison of the carbon bond and SAPRC photochemical mechanisms under conditions relevant to southeast Texas. Atmospheric Environmental 2008, 42, 5821. [CrossRef]

${ }^{73}$ Corrêa, S. M.; Arbilla, G.; Martins, E. M.; Quitério, S. L.; de Souza Guimarães, C.; Gatti, L. V. Five years of formaldehyde and acetaldehyde monitoring in the Rio de Janeiro downtown area. Atmospheric Environmental 2010, 44, 2302. [CrossRef]

${ }^{74}$ Corrêa, S. M.; Martins, E. M.; Arbilla, G. Formaldehyde and acetaldehyde in a high traffic street of Rio de Janeiro, Brazil. Atmospheric Environmental. 2003, 37, 23. [CrossRef] 